\title{
Identification Of Silymarin In Echinopus tenuisectus Family Compositae
}

\section{Echinopus tenuisectus التحري عن السليمارين في مكونات نبات}

\author{
Suha H. Al-Mohammadi \\ Enas J. Khadeem
}

College of Pharmacy/University of Baghdad

\section{Abstract.}

This study emphasized on the detection and identification of silymarin (Silybinin) Flavonoid in a newly studied, wild Iraqi plant, named Echinopus tenuisectus of Compositae family. The medicinal importance of silymarin on the one hand, and the absence of any phytochemical investigation on tenuisectus specie of Echinopus genus on the other hand, acquired this study its importance. Silymarin was identified in the plant extract of both, the aerial part's and the seed's extracts, by two chromatographic methods, first Thin Layer Chromatography (TLC) using TLC ready made Gf254 plates, UV detector at $254 \mathrm{~nm}$, and three different solvent systems in which the $R f$ value of the standard silymarin matched with the $R f$ value of the plant extract silymarin. HPLC was the other chromatographic method that proved the presence of silymarin in the plant extract by identical retention times. The result indicated that the silymarin content in the seed extract was higher than that in the plant extract of the aerial parts.

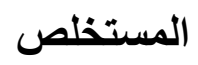

أكلات هذة الاراسـة على التحري عن السيليمارين وهي مـادة الفلافينوديـة تدرس لاول مرة في نبات بري عراقي مسمى Echinopus tenuisectus نظرا للاهمية الطبية لمادة السيليمارين من جهة وعدم وجود ايـة منشورات علمية تتناول المكونات الكيميائية لصنف tenuisectus لجنس Echinopus ، أخذت هذة الدراسة أهميتها . تم الكثف عن مادة السيليمارين في كل من مستخلص البذور ومستخلص النبات للاجزاء العلوية ، بواسطة طريقتين من طرق الكروماتوغرافية ، الأولى هي تقنية الكروماتوغرافية الطبقة الرقيقة TLC باستخدام رقائق TLC ذات النوعية Gf254 وكاثف الاشعة قوق البنفسية U.V بالطول الموجي 254 وثثلاثة محاليل ناقَلة مختلفة ، حيث

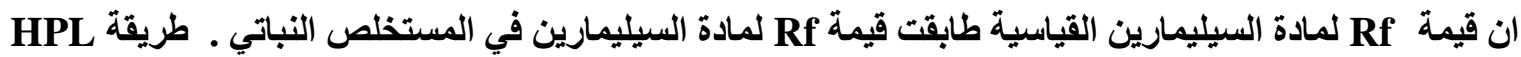


هـي الطريقـة الكروماتوغرافيـة الاخـرى التــي اكــت وجـود مـادة السـيليمارين فـي المسـتخلص النبـاتي بتطـابق retention times لكل من السيليمارين القياسي و السيليمارين في المستخلص النباني ـ كمـا واكلدت النتائج ان نسبة وجود مـادة السيليمارين في مستخلص البذور هي اعلى من نسبة وجود هذه المـادة في مستخلص النبات

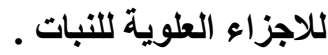

\section{Introduction}

The studied plant, Echinops tenuisectus, lanceolate, diminute. Heads are $5-7 \mathrm{~cm}$ belongs to the family Compositae (Figin diameter and Penicil is about $1 / 3$ as 1). It is an Iraqi wild plant first studied in Iraq. The Echinops genus consist of 100 spp. [1], very few reports investigated this family. The Echinopus tenuisectus is a perennial, $40-100 \mathrm{~cm}$ high. Stems are simple or branching from the base, sparsely cobwebby-canescent. Leaves are lanceolate or oblong-lanceolate, the lower ones are 10-15 cm long, 4-6cm wide, with triangular-lanceolate, prickly lobes, greenish, shiny, subglabrous above, densely whitish-tomentose below; stem-leaves are gradually smaller, subpinnatisect, prickly and the uppermost ones are narrow liner -

long as the involucres the bristles scabrous. Involucral bracts 12-14, the outer bracts as long as the penicil, narrow spathulate - deltoid, the intermediate ones subulate- attenuate, up to $2.5-3.5 \mathrm{~cm}$ long, produced into a long slender prickly horn, twice to twice and a half times as long as the outer ones, the innermost ones are about equal length, acute, fimbriate, connate to the middle. Pales of pappus barbellate, connate at base into a contiguous corona.

The distribution of this plant is in Sharaban, Diyalah, Badrah, - Upper Tigris Plain, 250-800 m [2].

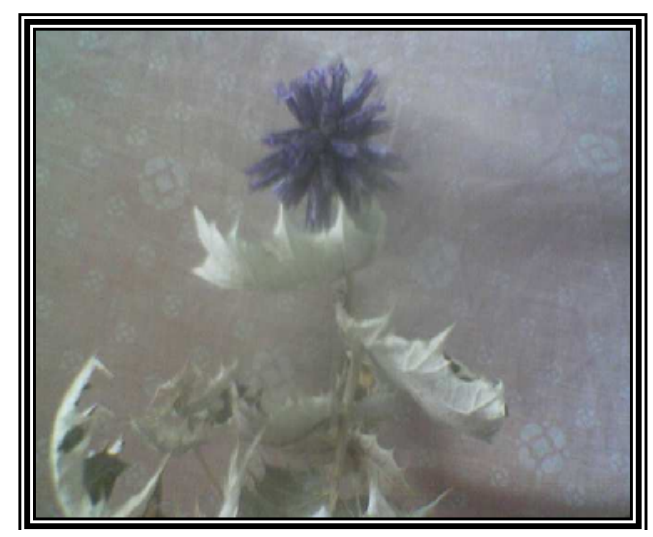

Figure 1: Photography of Echinops tenuisectus 
Flavonoids belong to the family of the benzo gamma-pyrones. More than 4000 different flavonoids are currently known; they are ubiquitous not only in the plant kingdom, where they are particularly abundant in the photosynthetic cells of higher plants, but also in the animal kingdom. [1,3]. Silymarin is a

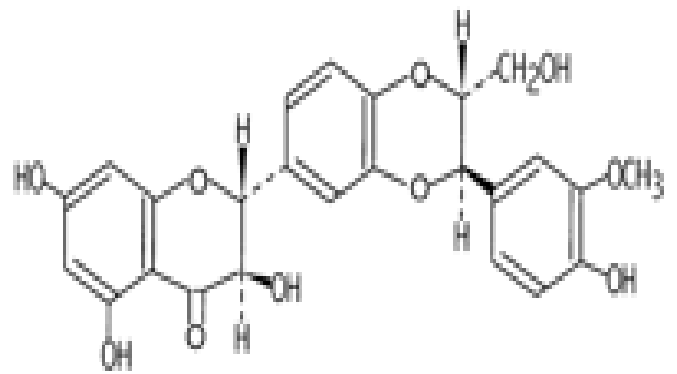

\section{Figure-2 : Structures of Silybinin formally called silymarin(13)}

Silymarin is soluble in acetone, ethyl acetate, methanol, and ethanol, sparingly soluble in chloroform and practically insoluble in water [13]. Of the isomers that constitute silymarin, Silybinin is the most active $[3,14]$. From a medical point of view, silymarin and Silybinin have been found to provide cytoprotection and, above all, hepatoprotection. Their mechanisms of action are still poorly understood. However, the data in the literature indicate that silymarin and Silybinin act in four different ways [3]:

1. As antioxidants, scavengers and regulators of the intracellular flavonolignan, which has been introduced fairly recently as a hepatoprotective agent $[4,5,6,7,8,9,10]$, is the most well known compound of the flavonoids; it is composed mainly of silibinin (or silybin), with small amounts of other silibinin stereoisomers, namely isosilybin, dihydrosilybin, silydianin and silychristin $[4,11]$. The structure of the constituents of silymarin (Fig-2) was clarified in the 1960s $[4,11,12]$.

content of glutathione $[15,16,17,18,19,20]$.

2. As cell membrane stabilizers and permeability regulators that prevent hepatotoxic agents from entering hepatocytes [21,22].

3. As promoters of ribosomal RNA synthesis, stimulating liver regeneration. [23,24,25].

4. As inhibitors of the transformation of stellate hepatocytes into myofibroblasts, the process responsible for the deposition of collagen fibers leading to cirrhosis. $[26,27,28]$.

The key mechanism that ensures hepatoprotection appears to be free radical scavenging [3].

Anti-inflammatory [25,28,29] and anticarcinogenic properties have also been 
documented

$[30,31,32]$.

Silymarin is included in the pharmacopoeia of many countries under the trademark LegalonTM or HepatronTM and is often used as supportive therapy in food poisoning due to fungi and in chronic liver disorders, such as steatosis [33] and alcohol-related liver disease [34].

\section{Materials and Methods}

The plant material was collected during July 2005 From Sharaban/Iraq. The plant was identified by the Department of Pharmacognosy, college of Pharmacy/University of Baghdad; and authenticated by the Herbarium of Baghdad University (Prof. Dr. Ali- AlMussawi) /Iraq.

Fifty grams of the powdered plant material (aerial part) were first defatted by reflux with $100 \mathrm{ml}$ of petroleum ether $60^{\circ}-80^{\circ} \mathrm{C}$ for one hour and then filtered. The defatted dried plant material was then extracted by reflux using $100 \mathrm{ml}$ of $70 \%$ ethanol for three hours. This step was repeated for four times, then the combined filtrates were evaporated under reduced pressure using Buchi rotary evaporator attached to vacuum pump at
The ripe seeds of Silybum marianum of the family Compositae serve as a main source of Silymarin [14]. This study indicates that Echinopus tenuisectus of Compositae family serves as another important source of that important medicinal compound.

$40^{\circ} \mathrm{C}$, to a thick residue of ethanol extract (F1). This residue was then hydrolyzed with $2 \mathrm{NHCl}$ in aqueous methanol (1:1) under reflux for three hours; the resultant solution was then partitioned with 100 $\mathrm{ml}$ of ethyl acetate (F2). This fraction was evaporated under reduced pressure to dryness, as shown in the following diagram (Fig-3). Then the same extraction method was repeated exactly on $50 \mathrm{gm}$ of the seed part of the same plant. 
Echinopus plant (50gm) (for aerial part and seed)

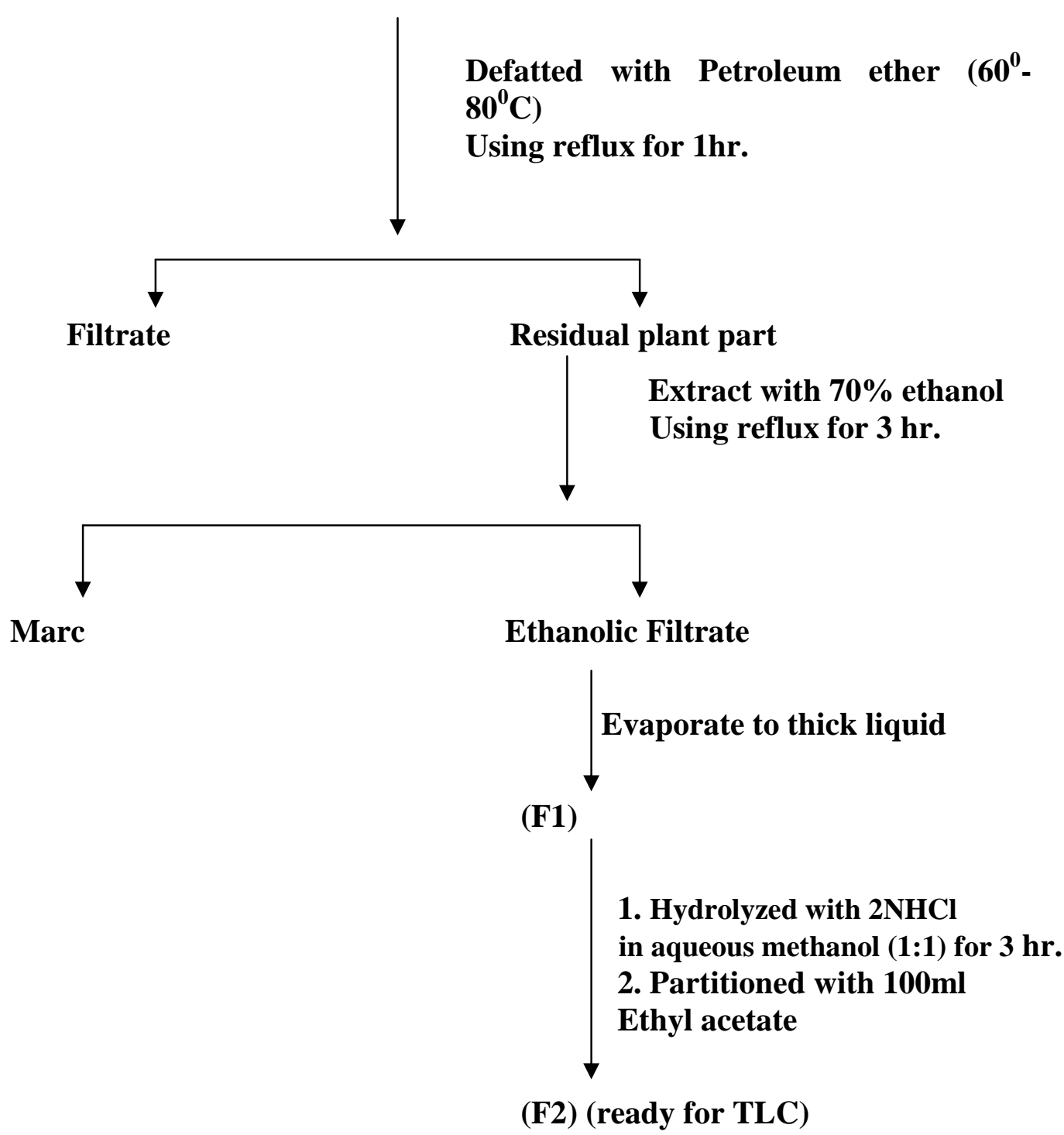

Figure-3: [Schematic representation of silymarin extraction from Echinopus tenuisectus]

\section{Identification of Silymarin in the plant extract.}

The Identification of Silymarin in the aerial plant extract and the seed extract, was performed first by TLC, using TLC ready made Gf254 plates, UV detector at 254 nm, Standard Silymarin, Standard
Silybinin and three different solvent systems that were [35]:

Solvent (1): chloroform: acetone: formic acid $[75: 16.5: 8.5]$ 
Solvent (2): Benzene: ethyl acetate [70:30]

Solvent (3): ethyl acetate: hexane [40:60]

\section{Results}

Most of the phytochemical studies on the natural sources of silymarin revealed that the fruit of Silybum marianum of the family Compositae is the main plant origin, but none, at all, was reported on
Then this identification was authenticated by HPLC with the standards silymarin and Silybinin

Echinopus tenuisectus). Since this plant resembles Silybum marianum in its shape, we found it worth to investigate its possible silymarin content.

\section{Identification of silymarin (Silybinin) by TLC.}

The detection of silymarin (Silybinin) was maintained for both the aerial plant extract and the seed extract, by TLC. Using three different solvent systems, in the presence of standard silymarin, standard Silybinin, and U.V detector (wave length $254 \mathrm{~nm}$ ) as demonstrated by the following TLC-plates. (Fig. 4, 5, $6)$. 


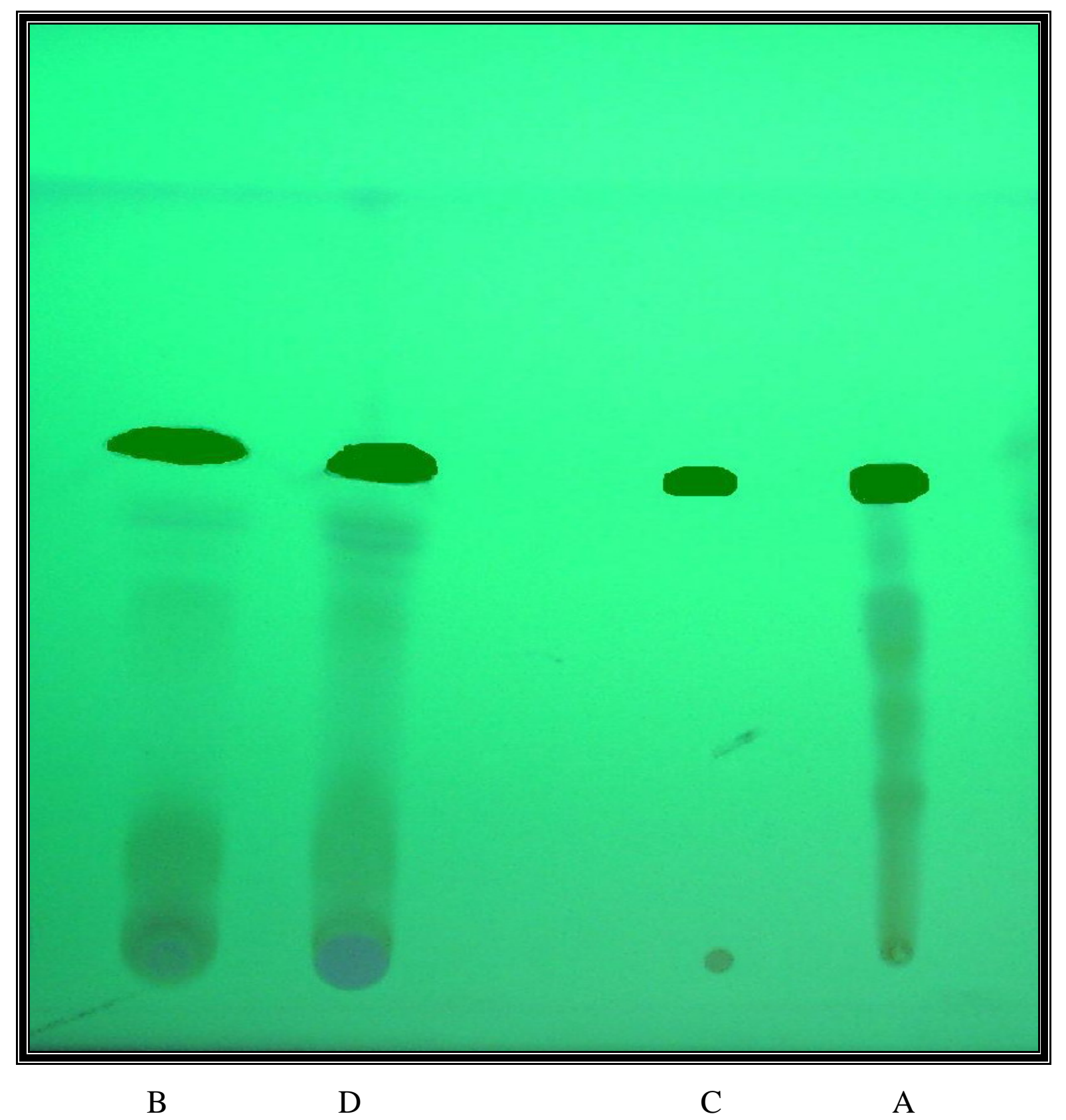

Figure (4): [TLC Gf254 plate of the aerial plant extract, seed extract, and standards using S1 mobile phase)

$\mathrm{A}=$ Standard silymarin

$\mathrm{B}=$ aerial plant extract

$\mathrm{C}=$ standard Silybinin

$\mathrm{D}=$ seed extract 


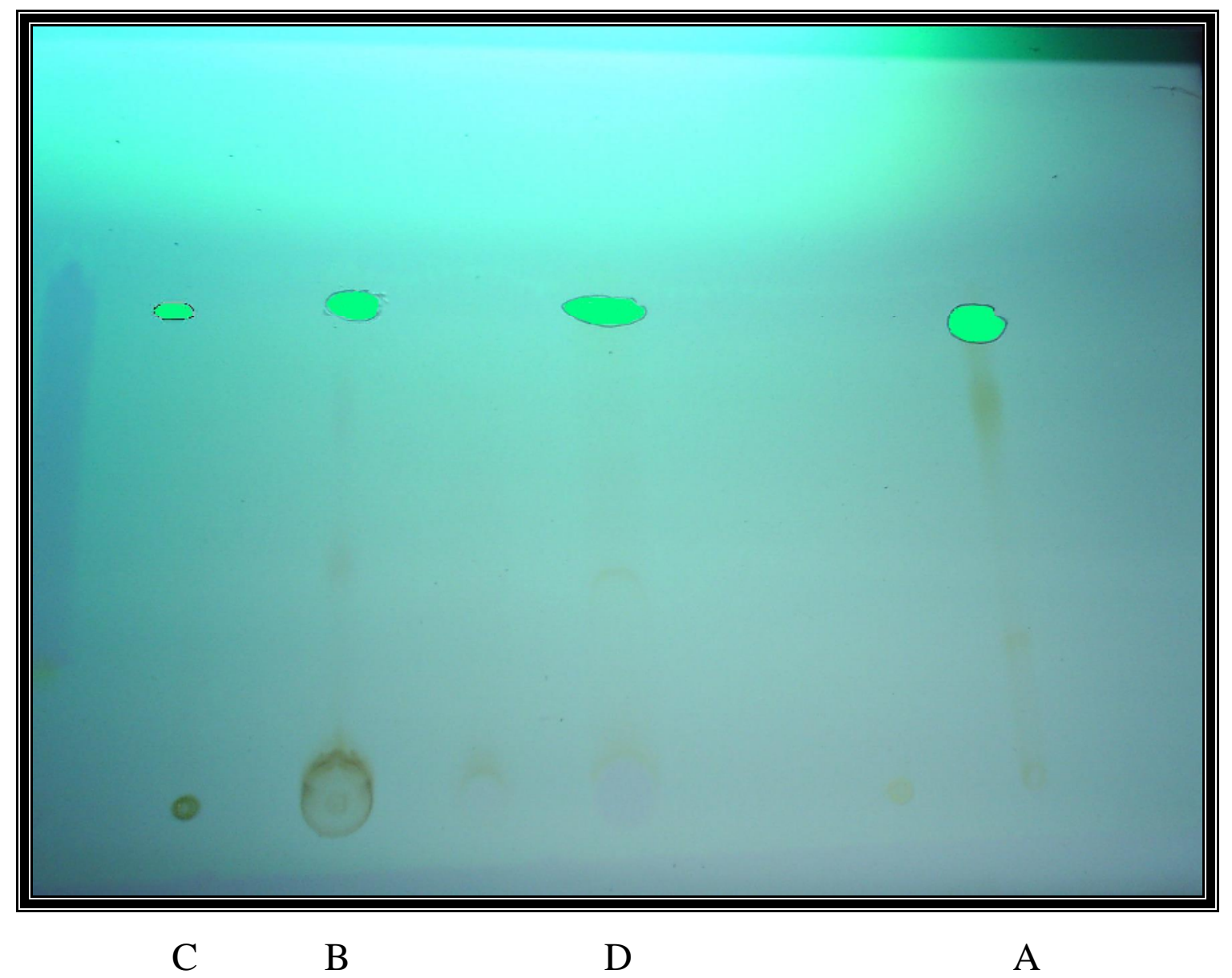

Figure (5): [TLC Gf254 plate of the aerial plant extract, Seed extract, and standards using S2 mobile phase)

$\mathrm{A}=$ Standard silymarin

$\mathrm{B}=$ aerial plant extract

$\mathrm{C}=$ standard Silybinin

$\mathrm{D}=$ seed extract 


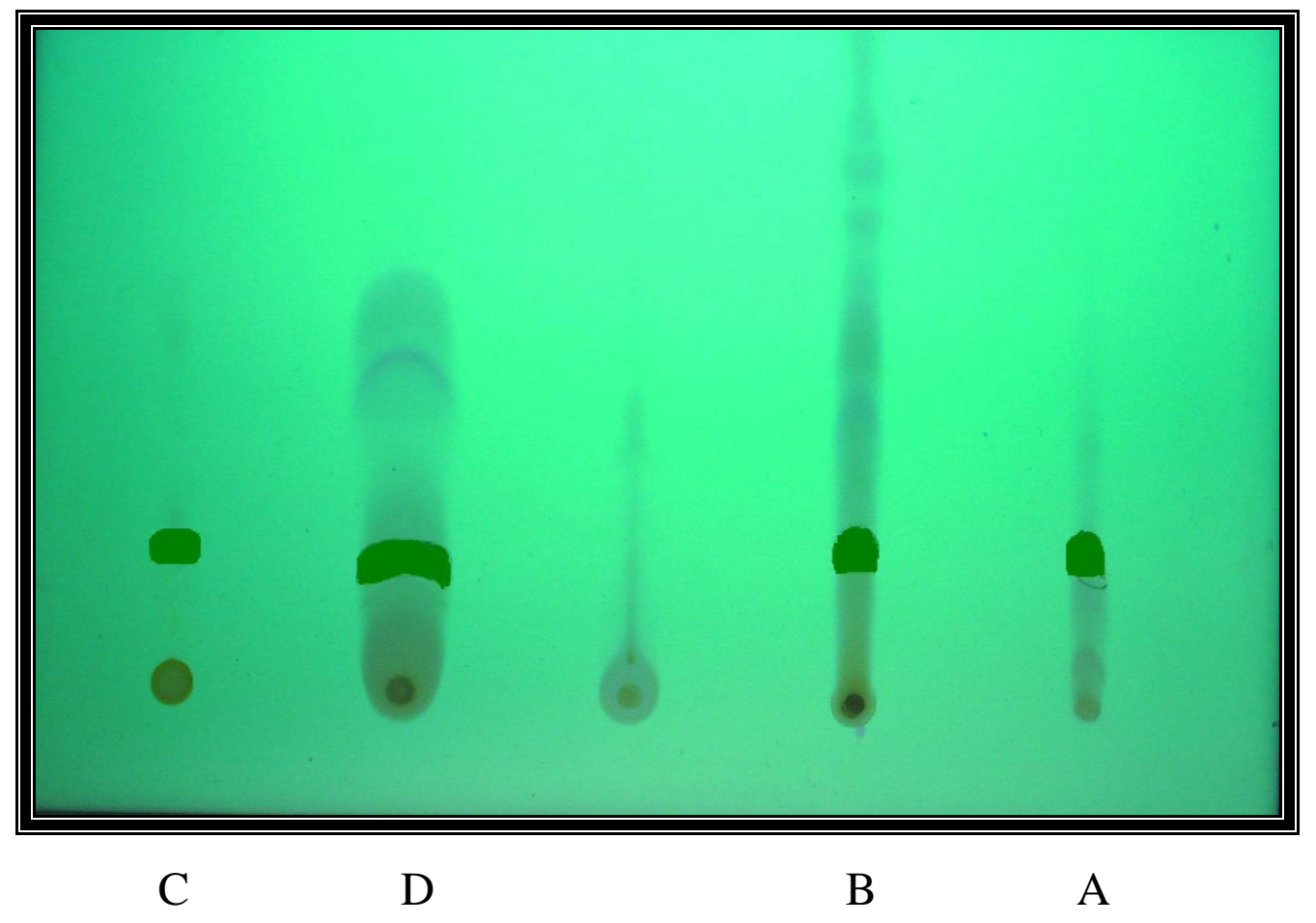

Figure (6): [TLC Gf254 plate of the aerial plant extract, seed extract, and standards using S3 mobile phase)

$\mathrm{A}=$ Standard silymarin

$\mathrm{B}=$ aerial plant extract

$\mathrm{C}=$ standard Silybinin

$\mathrm{D}=$ seed extract 
The Rf values of the standard silymarin, standard Silybinin, the aerial plant extract and the seed extract are tabled below table (1):

Table 1: Table of $R f$ values

\begin{tabular}{|l|c|c|c|c|}
\hline Solvent system & $\begin{array}{l}\text { Standard } \\
\text { silymarin }\end{array}$ & $\begin{array}{l}\text { Standard } \\
\text { Silybinin }\end{array}$ & $\begin{array}{l}\text { Aerial plant } \\
\text { extract }\end{array}$ & Seed extract \\
\hline S1 & 0.63 & 0.63 & 0.64 & 0.63 \\
\hline S2 & 0.57 & 0.57 & 0.58 & 0.57 \\
\hline S3 & 0.25 & 0.26 & 0.26 & 0.26 \\
\hline
\end{tabular}

\section{Identification of silymarin (Silybinin) by HPLC.}

Silymarin (Silybinin) was authenticated by HPLC .The HPLC conditions are listed in the following, table (2):

Table 2: HPLC conditions

\begin{tabular}{|l|l|}
\hline \multicolumn{2}{|c|}{ HPLC Conditions } \\
\hline Mobile phase & Methanol: water (50:50) \\
\hline Column & C18 25cm \\
\hline Flow rate & $1 \mathrm{ml} / \mathrm{min}$ \\
\hline Detector & $288 \mathrm{~nm}$ \\
\hline
\end{tabular}


The following charts were obtained (Fig. 7-10):

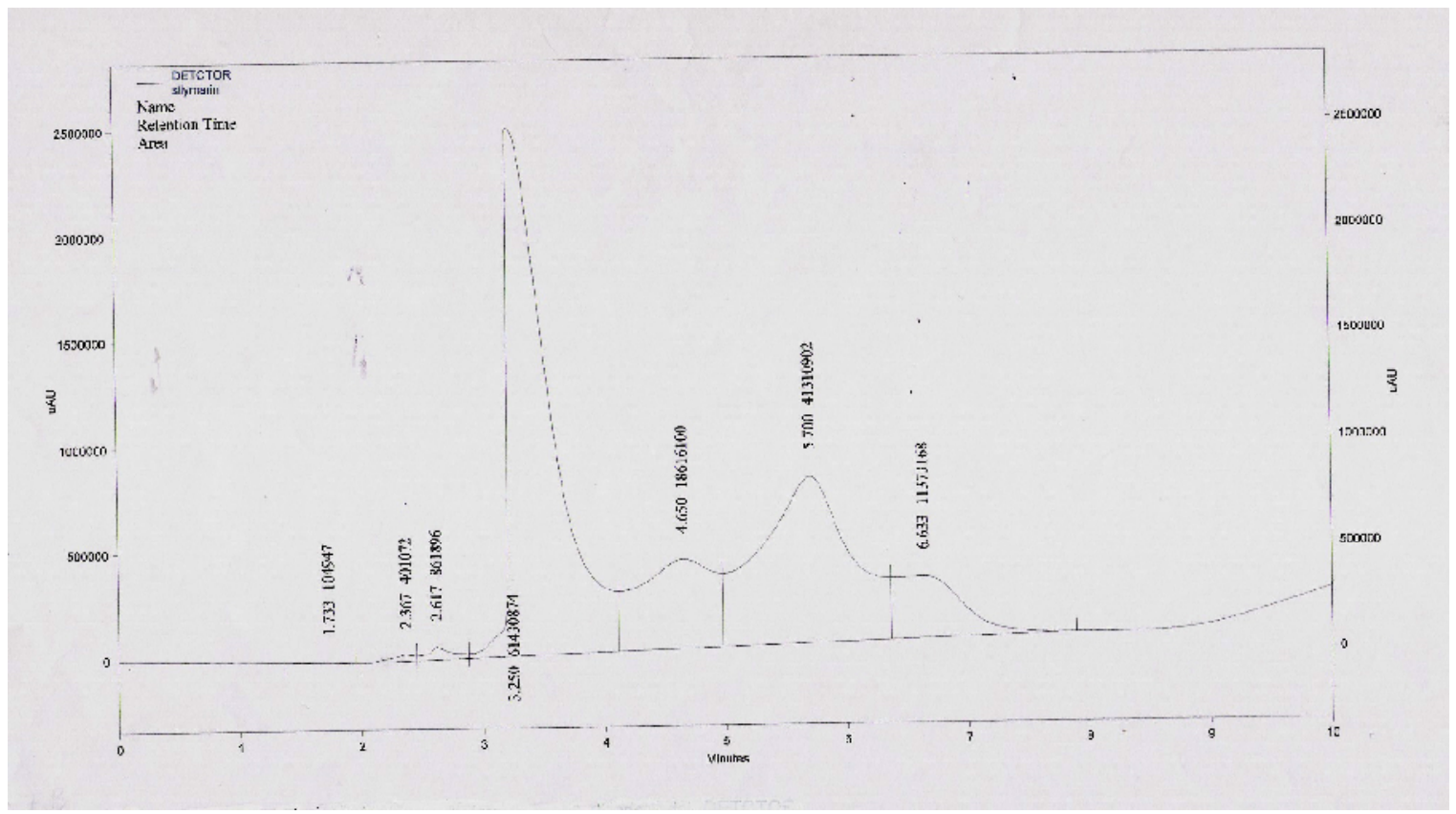

Figure (7): [HPLC of standard silymarin]

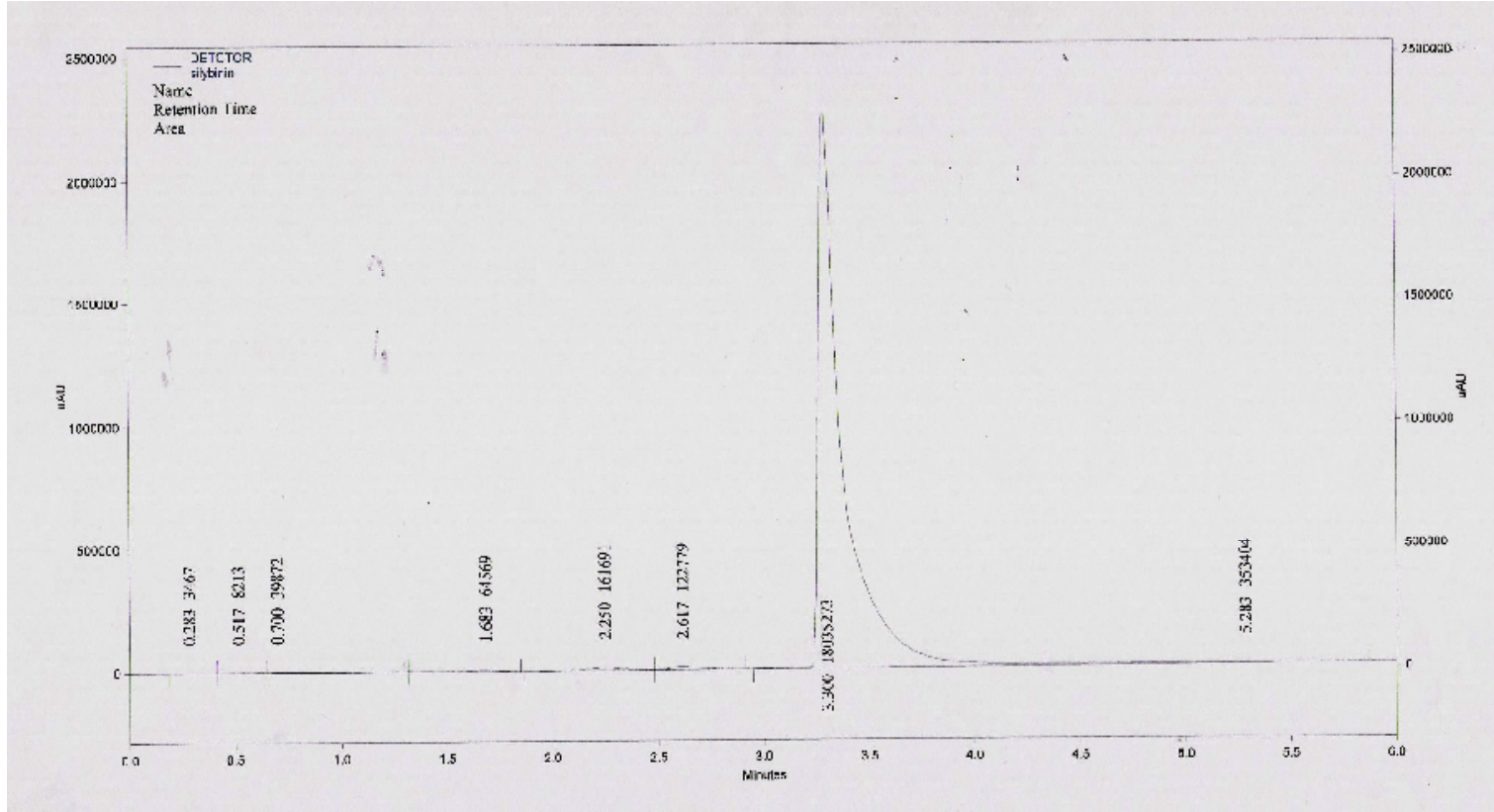

Figure (8): [HPLC of standard Silybinin] 


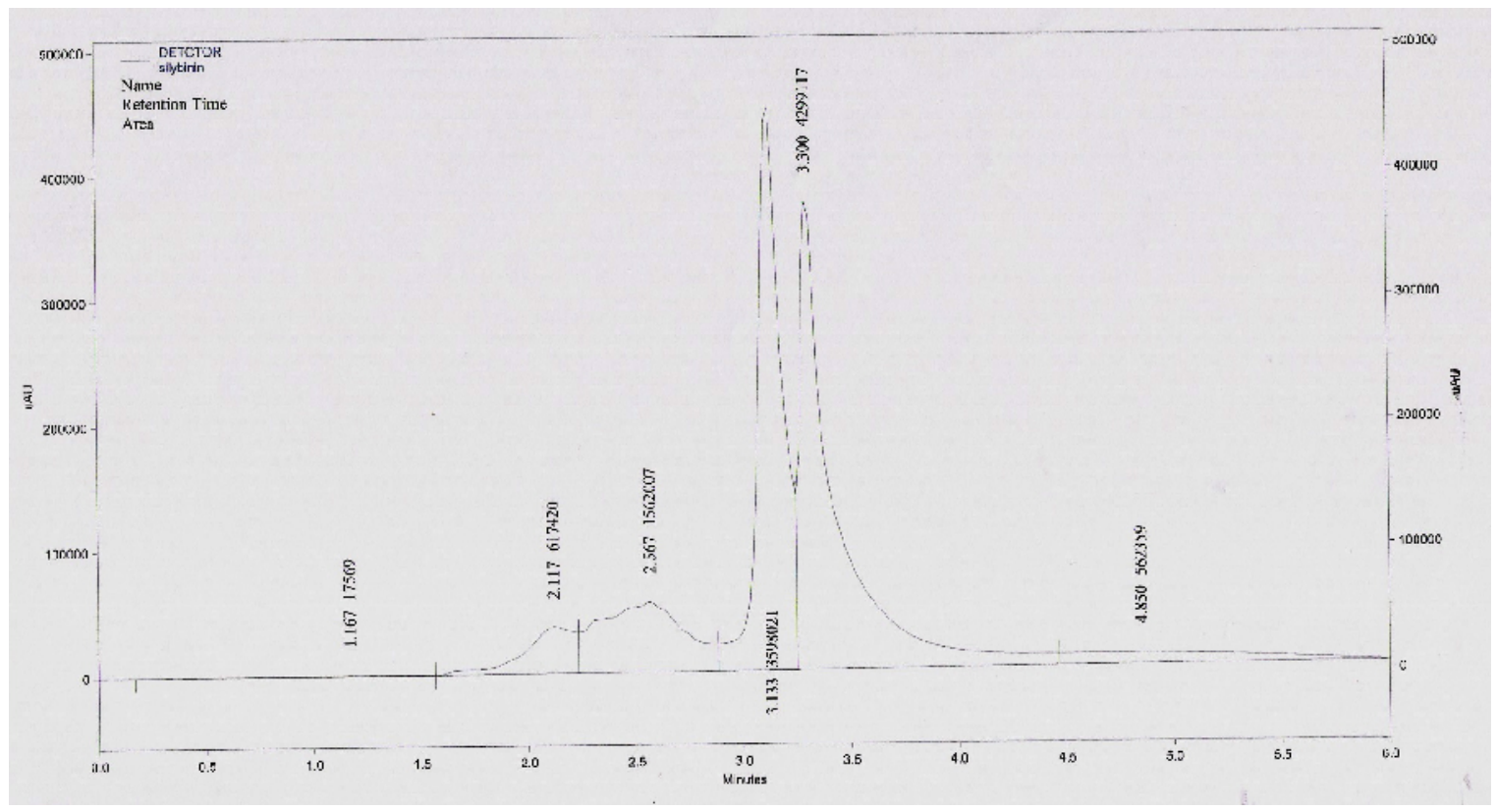

Figure (9): [HPLC of aerial plant extract]

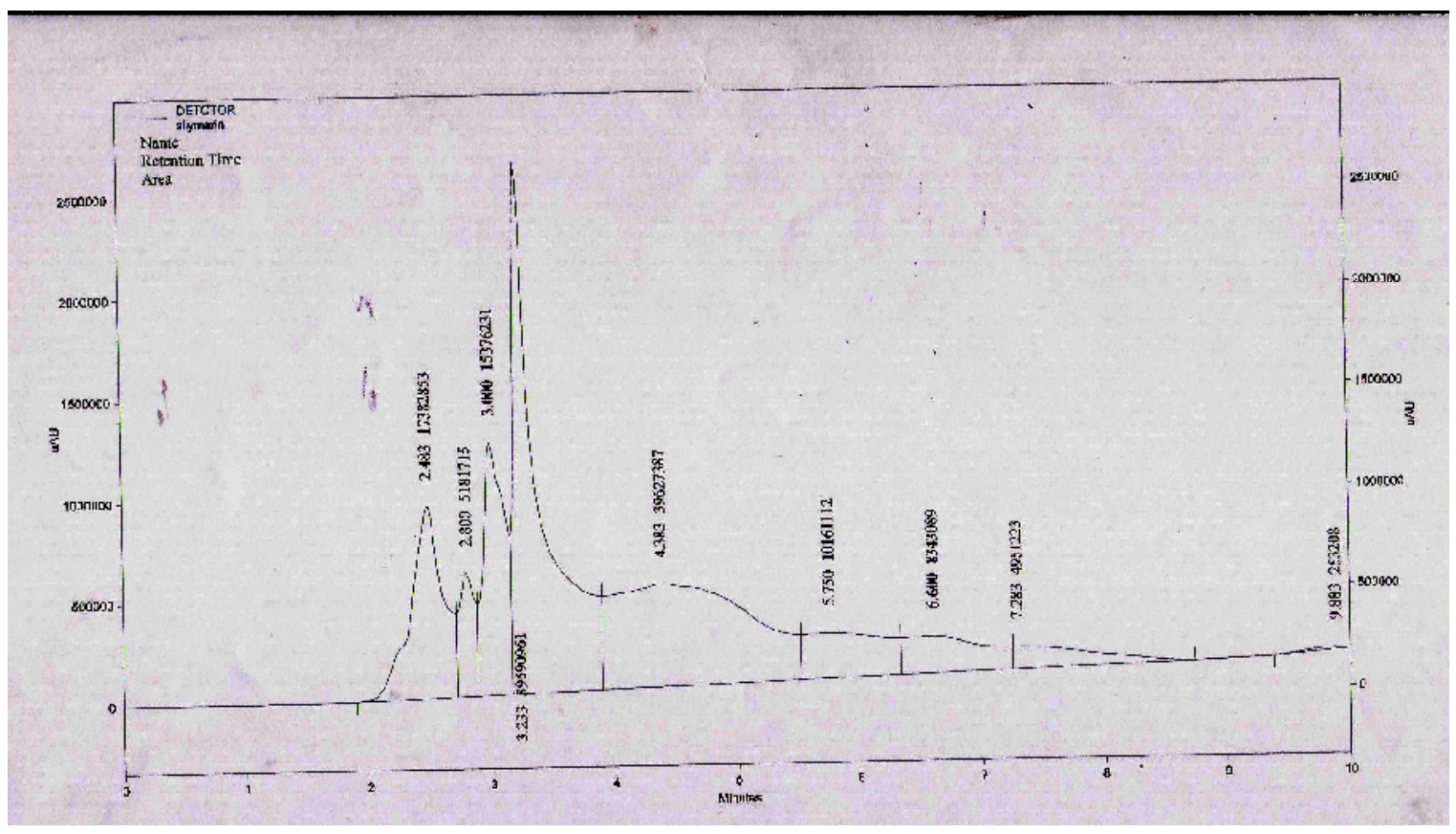

Figure (10): [HPLC of seed extract] 
It is obvious from the previous charts that both the aerial plant extract and the

\section{Calculations:}

The quantitative analysis of silymarin and Silybinin in the extracts from the HPLC chart represented as follow:

1. Percent yield in the aerial plant part extract: -

[AUC of the sample/AUC of the standard] $\times$ conc. of the standard.

The conc. of standard Silybinin use in $\mathrm{HPLC}=10 \mathrm{mg} / \mathrm{ml}$

The AUC of the aerial plant part extract

Silybinin in the HPLC chart $=4299117$

The AUC of the standard Silybinin in the HPLC chart $=18035273$

Therefore the equation will be:$[4299117 / 18035273] \times 10 \mathrm{mg} / \mathrm{ml}=$ $2.3837 \mathrm{mg} / \mathrm{ml}$

$2.3837 \mathrm{mg} / \mathrm{ml} \times$ dilution factor $(20)=$ $47.6745 \mathrm{mg} / \mathrm{ml} \rightarrow 0.04767 \mathrm{~g} / \mathrm{ml}$

\section{Conclusion}

1. Echinopus tenuisectus) serves as another source of silymarin_production.

2. Both the aerial plant parts and the seed part contain silymarin (Silybinin) Flavonoid glycoside. seed extract contain silymarin (Silybinin) Flavonoid glycoside.

The $\%$ of the silymarin content in the aerial plant part extract $=[0.04767 / 50]$ $\times 100=0.0953 \%$.

2. Percent yield in the seed extract:-

The conc. of standard Silybinin use in $\mathrm{HPLC}=10 \mathrm{mg} / \mathrm{ml}$

The AUC of the seed extract Silybinin in the HPLC chart = 39590961

The AUC of the standard Silybinin in the HPLC chart $=18035273$

Therefore the equation will be:[39590961/18035273] $\times 10 \mathrm{mg} / \mathrm{ml}=$ $21.9519 \mathrm{mg} / \mathrm{ml}$

$21.9519 \mathrm{mg} / \mathrm{ml} \times$ dilution factor $(20)=$ $439.038 \mathrm{mg} / \mathrm{ml} \rightarrow 0.439038 \mathrm{~g} / \mathrm{ml}$

The $\%$ of the silymarin content in the seed extract $=[0.439038 / 50]$ $\times 100=0.878 \%$.

3. The percentage of silymarin content in the seed extract is higher than that in the aerial plant part. 


\section{References}

1. Trease and Evans .(2002) "Pharmacognosy" fifteenth Edn. University of Nottingham, Nottingham, U.K pp.36, 415,246, 247.

2. K. H. Rechinger "Flora of Lowland Iraq" (1964) pp. 637.

3. F. Fraschini, G. Demartini, D. Esposti, "Clinical Drug Investigation" 22(1):51-65, 2002. pp.1.

4. Morazzoni P, Bombardelli E. (1995) "Silybum marianum (Carduus marianus)". Fitoterapia; LXVI: 3-42

5. Farghali H, Kamenikova L, Hynie S, et al. (2000). "Silymarin effects of intracellular calcium and cytotoxicity" a study in perfused rat hepatocytes after oxidative stress injury. Pharmacol Res; 41: 231-237

6. Siegers CP, Frühling A, Younes M. "Influence of dithiocarb, (+) catechin and silybine on halothane hepatotoxicity in the hypoxic rat model." Acta Pharmacol Toxicol (Copenh) 1983; 53: 125-129

7. Muriel P, Mourelle M. "Prevention by silymarin of membrane alterations in acute CCl4 liver damage." J Appl Toxicol 1990; 10: 275-279

8. Muriel P, Garciapia T, PerezAlvarez V, et al. "Silymarin protects against paracetamol-induced lipid

peroxidation and liver damage." J Appl Toxicol 1992; 12: 439-442

9. Mereish KA, Bunner DL, Ragland $\mathrm{DR}$, et al. "Protection against microcystin-LR-induced hepatotoxicity by silymarin": biochemistry, histopathology and lethality.Pharm Res 1991; 8: 273-277

10. Soto CP, Perez BL, Favari LP, et al. (1998). "Prevention of alloxaninduced diabetes mellitus in the rat by silymarin." Comp Biochem Physiol; 119C: 125-129

11. Valenzuela A, Garrido A. "Biochemical bases of the pharmacological action of the flavonoid silymarin and of its structural isomer silibinin.” Biol Res 1994; 27: 105-112

12. Tittle, G. and Wagner, $H$. Hochleistungs-flissig "Chromatographei von Silymarin" Germany J. Chromatography (1978); 153:227-232

13. Merck and CO., Inc. Rahway, N.J.:"The Merck Index" $8^{\text {th }}$ Ed. U.S.A. (1966), pp. 369.

14. Wagner H., Seligmann O., Horhammer L., Munster R. "The chemistry of silymarin (silybin), the active principle of the fruits of Silybum marianum (L). Gaertn. (Carduus 
marianus) (L). Arzneim. Forsch.”, 18: 688-696, 1968.[Medline]

15. Valenzuela A., Guerra R., Videla

L. A. "Antioxidant properties of the flavonoids silybin and (+)-cyanidanol-3: comparison with butylated hydroxyanisole and butylated hydroxytoluene." Planta Med., 5: 438440, 1986.

16. Comoglio A., Leonarduzzi G., Carini R., Busolin D., Basaga H., Albano E., Tomasi A., Poli G., Morazzoni P., Magistretti M. J. "Studies on the antioxidant and free radical scavenging properties of IdB1016 a new flavanolignan complex. Free Radical Res. Commun.", 11: 109-115, 1990.[Medline]

17. Valenzuela A, Guerra R. "Differential effect of silybin on the Fe2+ -ADP and t-butyl hydroperoxideinduced microsomal lipid peroxidation". Experientia 1986; 42: 139-141

18. Mira L, Silva M, Manso CF. "Scavenging of reactive oxygen species by silibinin dihemisuccinate". Biochem Pharmacol 1994; 48: 753-759

19. Bosisio E, Benelli $\mathrm{C}$, Pirola $\mathrm{O}$. "Effect of the flavanolignans of Silybum marianum L. on lipid peroxidation in rat liver microsomes and freshly isolated hepatocytes." Pharmacol Res 1992; 25: $147-154$

20. Cavallini L, Bindoli A, Siliprandi N. "Comparative evaluation of antiperoxidative action of silymarin and other flavonoids." Pharmacol Res Commun 1978; 10: 133-136

21. P, Mourelle M. "Prevention by silymarin of membrane alterations in acute CCl4 liver damage." J Appl Toxicol 1990; 10: 275-279

22. Farghali H, Kamenikova L, Hynie $\mathrm{S}$, et al. "Silymarin effects of intracellular calcium and cytotoxicity": a study in perfused rat hepatocytes after oxidative stress injury. Pharmacol Res 2000; 41: 231-237

23. Magliulo E, Carosi PG, Minoli L, et al. "Studies on the regenerative capacity of the liver in rats subjected to partial hepatectomy and treated with silymarin." Arzneimittelforschung 1973; 23: $161-167$

24. Sonnenbichler J, Zetl I. "Biochemical effects of the flavonolignane silibinin on RNA, protein and DNA synthesis in rat livers. "In: Cody V, Middleton E, Harborne JB, editors. Plant flavonoids in biology and medicine: biochemical, pharmacological 
and structure-activity relationship. New York: Alan R Liss Inc., 1986: 319-331

25. Luper S. "A review of plants used in the treatment of liver disease": part I. Altern Med Rev 1998; 3: 410-421

26. Fuchs EC, Weyhenmeyer R, Weiner $\mathrm{OH}$. "Effects of silibinin and of a synthetic analogue on isolated rat hepatic stellate cells and myofibroblasts." Arzneimittelforschung 1997; 47: 13831387

27. Boigk G, Stroedter L, Herbst H, et al. "Silymarin retards collagen accumulation in early and advanced biliary fibrosis secondary to complete bile duct obliteration in rats." Hepatology 1997; 26: 643-649

28. Favari L, Perez-Alvarez V. "Comparative effects of colchicine and silymarin on $\mathrm{CCl} 4$ chronic liver damage in rats." Arch Med Res 1997; 28: 11-17

29. De la Puerta R, Martinez E, Bravo L, et al. "Effect of silymarin on different acute inflammation models and on leukocyte migration." J Pharm Pharmacol 1996; 48: 968-970

30. Katiyar SK, Korman NJ, Mukhtar $\mathrm{H}$, et al. "Protective effects of silymarin against photocarcinogenesis in a mouse skin model.” J Natl Cancer Inst 1997; 89: $556-566$
31. Lahiri-Chatterjee M, Katiyar SK, Mohan RB, et al. "A flavonoid antioxidant, silymarin, affords exceptionally high protection against tumor promotion in the SENCAR mouse skin tumorigenesis model." Cancer Res 1999; 59: 622-632

32. Zhao J, Lahiri-Chatterjee $M$, Sharma Y, et al. "Inhibitory effect of a flavonoid antioxidant silymarin on benzoyl peroxide-induced tumor promotion, oxidative stress and inflammatory responses in SENCAR mouse skin." Carcinogenesis 2000; 21: 811-816

33. Skottova N, Kreeman V. "Silymarin as a potential hypocholesterolaemic drug." Physiol Res 1998; 47: 1-7

34. Ferenci P, Dragosics B, Dittrich H, et al. "Randomized controlled trial of silymarin treatment in patients with cirrhosis of the liver." J. Hepatol 1989; 9:105-113.

35. H.Wagner. Plant drug analysis, thin layer chromatography atlas, 1984, p.190191. 
